\title{
Plasmid-mediated quinolone resistance in Salmonella serotypes isolated from chicken carcasses in Turkey
}

\author{
Zafer Ata ${ }^{1}$, Artun Yibar $^{2}$, Erdem Arslan ${ }^{3}$, Kaan Mustak ${ }^{4}$, Elcin Gunaydin ${ }^{5}$ \\ ${ }^{1}$ Military Veterinary School and Educational Central Commandership, Bursa, Turkey \\ ${ }^{2}$ Uludag University, Faculty of Veterinary Medicine, Department of Food Hygiene and Technology, \\ ${ }^{3}$ Department of Pharmacology and Toxicology, Bursa, Turkey \\ ${ }^{4}$ Ankara University, Faculty of Veterinary Medicine, Department of Microbiology, Ankara, Turkey \\ ${ }^{5}$ Veterinary Control Central Research Institute, Bacteriological Diagnostic Laboratory, Ankara, Turkey
}

Received January 13, 2014

Accepted September 17, 2014

\begin{abstract}
Quinolones have been extensively used for treatment of a variety of invasive and systemic infections of salmonellosis. Widespread use of these agents has been associated with the emergence and dissemination of quinolone-resistant pathogens. The quinolone resistance and plasmid-mediated quinolone resistance determinants ( $q n r \mathrm{~A}, q n r \mathrm{~B}, q n r \mathrm{~S}$ and $\left.a a c\left(6^{\prime}\right)-I b-c r\right)$ of 85 Salmonella isolates from chicken carcasses were investigated in this study. Isolates were serotyped according to the Kauffman-White-Le Minor scheme, and broth microdilution method was used to determine quinolone resistance. Plasmid-mediated quinolone resistance genes were investigated by real-time PCR and positive results were confirmed by sequencing. Among the Salmonella isolates, 30/85 (35\%) and 18/85 (21\%) were found to be resistant to enrofloxacin (MIC $\geq 2 \mathrm{mg} / \mathrm{ml}$ ), and danofloxacin (MIC $\geq 2 \mathrm{mg} / \mathrm{ml}$ ), respectively. All the isolates were negative for $q n r \mathrm{~A}, q n r \mathrm{~B}$ and $a a c\left(6^{\prime}\right)-I b-c r$ genes, nevertheless $2 \%$ (S. Brandenburg and $S$. Dabou) were positive for $q n r \mathrm{~S}$ ( $q n r \mathrm{~S} 1$ determinant). This study is the first and unique investigating the plasmidmediated quinolone resistance determinants of Salmonella isolated from chicken carcasses in Turkey.
\end{abstract}

Quinolone susceptibility, qnr, aac(6')-Ib-cr, real-time PCR, minimal inhibition concentration

Salmonellae are among the most common Gram negative pathogens implicated in foodborne illnesses and also a major public health concern worldwide (Guner et al. 2012). Chicken meat, fresh and processed meat and eggs have been the most commonly incriminated foodstuffs in several outbreaks of salmonellosis (Tauxe 1991; Benenson and Chin 1995; Mead et al. 1999). Quinolone resistant Salmonella isolates have been documented in numerous locations with variable prevalence including Japan (Taguchi et al. 2009) and Brasil (Ferrari et al. 2011). Molbak et al. (2002) reported that quinolone resistance in Salmonella spp. isolated in Denmark had increased almost 10 fold in five years. Unfortunately, these results indicate that widespread fluoroquinolone use for the treatment of infections both in human and in veterinary medicine has led to increasing numbers of quinolone resistant Salmonella isolates.

Several reports in Turkey have evaluated the plasmid-mediated quinolone resistant (PMQR) in animal isolates of Escherichia coli strains (Cengiz et al. 2012; Mustak et al. 2012). However, this study is the first and unique one investigating the PMQR determinants of Salmonella isolated from chicken carcasses in Turkey. The aim of this study was to investigate the presence of PMQR determinants of $q n r \mathrm{~A}, q n r \mathrm{~B}, q n r \mathrm{~S}$, $a a c(b)-1 b-c r$ in Salmonella strains isolated from chicken carcasses between 2005 and 2009 in the Bursa and Ankara provinces of Turkey.

Address for correspondence:

Dr. Artun Yibar

Department of Food Hygiene and Technology

Faculty of Veterinary Medicine, Uludag University

16059, Gorukle Campus, Bursa, Turkey

Phone: +90224 2941338
Fax: +90 2242941202
E-mail: artunyibar@hotmail.com
http://actavet.vfu.cz/ 
Materials and Methods

Bacterial strains

A total of 85 Salmonella spp. strains which were previously isolated from chicken carcasses in Bursa and Ankara provinces of Turkey between 2005 and 2009 were obtained from Uludag University, Faculty of Veterinary Medicine Department of Food Hygiene and Technology laboratory. All presumptive Salmonella-positive isolates were confirmed by biochemical tests according to ISO 6579:2002 and serotyped according to the KauffmanWhite-Le Minor scheme (ISO 2002; Grimont and Weill 2007).

\section{Antimicrobial susceptibility testing}

Enrofloxacin and danofloxacin MICs were determined by broth microdilution method according to Clinical and Laboratory Standards Institute (CLSI) guidelines (CLSI 2012a). Enrofloxacin and danofloxacin analytical standards were obtained from Fluka (Sleinheim, Germany) and dissolved in 20:80 methanol/phosphate buffered saline (v/v). Salmonella cultures were prepared in Mueller-Hinton Broth at $37^{\circ} \mathrm{C}$ for $16-20 \mathrm{~h}$. Freshly prepared stock solution was sterilized using $0.20 \mu \mathrm{m}$ single-use filter units (Minisart ${ }^{\mathbb{Q}}$, Sartorius Stendim Biotech, Göttingen, Germany). Enrofloxacin and danofloxacin dilutions ranging from 0.008 to $256 \mathrm{mg} / 1$ were prepared in Mueller-Hinton Broth. Inoculants with a density equivalent to $0.5 \mathrm{McFarland}$ turbidity standard were prepared and each of enrofloxacin and danofloxacin dilutions were added into 96 well plates (Thermo Scientific, Epsom, $\mathrm{UK})$. After incubating at $37^{\circ} \mathrm{C}$ for $16-20 \mathrm{~h}$, the MICs were defined as the minimum concentration of enrofloxacin and danofloxacin inhibiting growth of bacteria. The optical densities (ODs) of the cultures were measured at a wave length of $595 \mathrm{~nm}$ (iMark ${ }^{\mathrm{TM}}$, Bio-Rad, Hercules, CA, USA). Escherichia coli ATCC 25922 was used as control for antimicrobial susceptibility testing. Susceptibility to enrofloxacin and danofloxacin were interpreted according to CLSI (CLSI 2012b).

\section{Detection of PMQR genes}

Plasmids were extracted from Salmonella isolates with a DNA-spin ${ }^{\mathrm{TM}}$ Plasmid DNA Purification Kit (iNtRON Biotechnology, Seoul, Republic of Korea) according to manufacturer's recommendations. Presence of PMQR was investigated with $q n r \mathrm{~A}, q n r \mathrm{~B}$, qnrS, aac(6')- $\mathrm{Ib}-\mathrm{cr}$ specific primers designed for this study by real-time PCR using Melting Curve Analysis. The PMQR gene sequences were acquired from NCBI Data Bank (NCBI Data Bank) and sequence analyses were made by ClustalW programme (ClustalW2). Primers aiming secured sequences were designed manually and tested with Primer-Blast (NCBI/Primer-BLAST).

A total of 85 isolates were screened by $q n r$ determinants using specific primers for $q n r$ A $\left(5^{\prime}-\mathrm{CCG}\right.$ AGT TTG GCC AGA TAG AC-3' [forward] and 5' CTG CTC CAG CAA ATC CTG TT-3' [reverse]), qnrB (5'-CAG TAC ACC GGC CAG AAA GT-3' [forward] and 5'-TTG AAA TGG CAC ATG CTG AT-3' [reverse]), and $q n r \mathrm{~S}$ (5'ACG ACA TTC GTC AAC TGC AA-3' [forward] and 5'-CGA AGA TCT GCG ACA TCA AA-3' [reverse]) and for $a a c\left(6^{\prime}\right)-I b-c r$ (5'-TGA CCT TGC GAT GCT CTA TG-3' [forward] and 5' TGG TCT ATT CCG CGT ACT CC-3' [reverse]). Amplification was carried out in a $50 \mu 1$ volume containing $0.2 \mu \mathrm{M}$ each of dNTP and the primer pairs at concentrations each of $2.5 \mathrm{pM}$ and $2.5 \mathrm{U}$ of Taq DNA polymerase (MBI Fermentas, Vilnius, Lithuania), 2 $\mu \mathrm{M} \mathrm{MgCl}_{2}$ and $1 \times$ EvaGreen. Isolated DNA $(3 \mu \mathrm{l})$ was used as a template. The PCR was performed using an ABI 7500 Fast Real-time PCR system (Applied Biosystems, Foster City, CA, USA) under the following conditions: initial denaturation for $10 \mathrm{~min}$ at $95{ }^{\circ} \mathrm{C} ; 35$ cycles of denaturation for $10 \mathrm{~s}$ at $94{ }^{\circ} \mathrm{C}$, annealing for $15 \mathrm{~s}$ at $55{ }^{\circ} \mathrm{C}$ and extension for $10 \mathrm{~s}$ at $72{ }^{\circ} \mathrm{C}$; and final extension for $5 \mathrm{~min}$ at $72{ }^{\circ} \mathrm{C}$. The temperature had been raised to $95{ }^{\circ} \mathrm{C}$ from $50{ }^{\circ} \mathrm{C}$ by the speed of $0.5^{\circ} \mathrm{C} / \mathrm{s}$ in the melting curve analysis, meanwhile the specification of PCR products had been tested by reading the fluorescent constantly.

PCR products were purified and then sequenced with 3130 Genetic Analyzer (Applied Biosystems, Foster City, CA, USA) by Sanger method. The sequences were compared and confirmed with the GenBank nucleotide database using the BLAST (Basic Local Alignment Search Tool) program (NCBI/BLAST Home).

\section{Results}

Serotyping results showed that majority of the Salmonella isolates were $S$. Enteritidis serotype $(\mathrm{n}=42)$. MICs of Salmonella isolates ranged from $0.016 \mathrm{mg} / \mathrm{l}$ to higher than 256 $\mathrm{mg} / \mathrm{l}$ for enrofloxacin and danofloxacin. Among the 85 Salmonella isolates, 11 (13\%) and 8 $(9 \%)$ were resistant to enrofloxacin and danofloxacin (MIC $\geq 4 \mathrm{mg} / \mathrm{ml}$ ), respectively. Fiftyfive isolates (65\%) and 19 isolates (22\%) were exhibited as susceptible and at intermediate level of susceptibility, respectively, to enrofloxacin. Variable level of susceptibility was also noted for danofloxacin. A total of 67 isolates $(79 \%)$ were determined as susceptible, and 10 isolates (12\%) were intermediate susceptible (Tables 1 and 2). Quinolone resistance reached MIC in Salmonella serotypes of $\geq 256 \mathrm{mg} / \mathrm{ml}$ for enrofloxacin (2\%) and danofloxacin (5\%). The MICs of enrofloxacin and danofloxacin for qnr-containing Salmonella isolates ranged from $16 \mathrm{mg} / \mathrm{ml}$ to $64 \mathrm{mg} / \mathrm{ml}$. 
The $q n r \mathrm{~S}$ gene was identified in two isolates $(2 \%)$ of Salmonella strains ( $S$. Brandenburg and $S$. Dabou) isolated from chicken carcasses, whereas $q n r \mathrm{~A}, q n r \mathrm{~B}$ and $a a c\left(6^{\prime}\right)-I b-c r$ were not detected (Table 3).

Table 1. Determined MIC values for Salmonella serotypes to enrofloxacin and danofloxacin.

\begin{tabular}{|c|c|c|c|}
\hline \multirow[t]{2}{*}{ Salmonella serotypes } & \multirow[t]{2}{*}{ Number of serotypes } & \multicolumn{2}{|c|}{ Range of MIC values (mg/ml) } \\
\hline & & Enrofloxacin & Danofloxacin \\
\hline S. Agona & 1 & 0.128 & 0.064 \\
\hline$S$. Brandenburg & 4 & $4-64$ & $2-64$ \\
\hline S. Chincol & 1 & 0.064 & 0.064 \\
\hline S. Corvallis & 7 & $0.032-2$ & $0.032-2$ \\
\hline$S$. Dabou & 4 & $0.064-32$ & $0.016-16$ \\
\hline$S$. Emek & 1 & 0.064 & 1 \\
\hline$S$. Enteritidis & 42 & $0.032-4$ & $0.016-4$ \\
\hline$S$. Essen & 1 & 0.512 & 0.256 \\
\hline$S$. Hadar & 5 & $0.032-128$ & $0.032-256$ \\
\hline$S$. Infantis & 1 & 2 & 2 \\
\hline$S$. Kentucky & 6 & $0.064->256$ & $0.032-256$ \\
\hline S. Kingston & 1 & 0.064 & 0.032 \\
\hline$S$. Senftenberg & 1 & 0.064 & 0.064 \\
\hline$S$. Typhimurium & 9 & $0.064->256$ & $0.016-256$ \\
\hline S. Virchow & 1 & 1 & 0.256 \\
\hline
\end{tabular}

Table 2. Number of Salmonella strains susceptible, intermediate susceptible, and/or resistant to enrofloxacin and danofloxacin.

\begin{tabular}{lccc}
\hline Antimicrobials & $\mathrm{S} / \mathrm{I} / \mathrm{R}^{\mathrm{a}}$ & Concentration $(\mathrm{mg} / \mathrm{ml})$ & Number $(\%)$ \\
\hline \multirow{2}{*}{ Enrofloxacin } & $\mathrm{S}$ & $\leq 1$ & $55(65)$ \\
& $\mathrm{I}$ & 2 & $19(22)$ \\
& $\mathrm{R}$ & $\geq 4$ & $11(13)$ \\
Danofloxacin & $\mathrm{S}$ & $\leq 1$ & $67(79)$ \\
& $\mathrm{I}$ & 2 & $10(12)$ \\
\hline
\end{tabular}

a $\mathrm{S} / \mathrm{I} / \mathrm{R}$, susceptible/intermediate susceptible/resistant

Table 3. Resistance profile of qnr-positive Salmonella serotypes.

\begin{tabular}{|c|c|c|c|c|c|c|}
\hline \multirow[t]{2}{*}{$\begin{array}{l}\text { Salmonella } \\
\text { serotypes }\end{array}$} & \multicolumn{2}{|c|}{$\mathrm{MIC}(\mathrm{mg} / \mathrm{ml})$} & \multicolumn{4}{|c|}{ Plasmid mediated quinolone resistance determinants } \\
\hline & Enrofloxacin & Danofloxacin & $q n r \mathrm{~S}$ & $q n r \mathrm{~A}$ & $q n r \mathrm{~B}$ & $a a c\left(6^{\prime}\right)-I b-c r$ \\
\hline S. Brandenburg & 64 & 64 & Positive & ND & ND & ND \\
\hline$S$. Dabou & 32 & 16 & Positive & ND & ND & ND \\
\hline
\end{tabular}

$\mathrm{ND}=$ not detected 


\section{Discussion}

Quinolone resistance in Salmonella has been observed all over the world (Angulo et al. 2000; Helmuth 2000). In the present study, 11 (13\%) and 8 (9\%) Salmonella isolates were found to be resistant to enrofloxacin and danofloxacin, respectively. The results have also shown that Salmonella strains were highly resistant to quinolones. High resistances $(\geq 256 \mathrm{mg} / \mathrm{ml}$ ) to enrofloxacin and danofloxacin in two $S$. Hadar, one $S$. Kentucky and one $S$. Typhimurium may be due to mutations in quinolone resistance determining regions. Resistance to quinolones in Salmonella spp. have been reported by previous studies in chickens (Wang et al. 2006; De Jong et al. 2014).

The PMQR determinants are distributed among Enterobacteriaceae, including Salmonella, worldwide (Cattoir and Nordmann 2009). The $q n r \mathrm{~A}, q n r \mathrm{~B}, q n r \mathrm{~S}$, and $a a c\left(6^{\prime}\right)-I b-c r$ genes are the most commonly identified resistance determinants in Turkey (Nazik et al. 2009; Ozgumus et al. 2009). The prevalence of $q n r$ genes among the $E$. coli isolates obtained from animals in the EU and Turkey ranged between 3\% and 15\% (Veldman et al. 2011; Cengiz et al. 2012). In another study from Turkey, Nazik et al. (2009) reported qnr genes in Enterobacter spp., E. coli and $K$. pneumoniae. In agreement with previous studies (Kehrenberg et al. 2006; Avsaroglu et al. 2007), our results confirmed the presence of $q n r S$ gene associated with fluoroquinolone resistance in two different Salmonella isolates from Turkey. In contrast, Yu et al. (2011), reported that all Salmonella isolates were negative for qnr genes, whereas a high prevalence (37.1\%) of $a a c\left(6^{\prime}\right)-I b-c r$ was found.

The presence of PMQR determinants has been reported in clinical isolates of $S$. Enteritidis (Cheung et al. 2005). In contrast, PMQR genes were not detected in Salmonella strains isolated from ready to eat foods and chicken meat as reported by $\mathrm{Kim}$ et al. (2011). Low prevalence $(2 \%)$ of $q n r$ genes in Salmonella isolates in comparison with other studies was observed. These genes were located on plasmids which are frequently associated with Enterobacteriaceae isolated from various foods and humans (Hopkins et al. 2007; Ferrari et al. 2011).

Even though the topic is widely investigated by several researchers, to our knowledge, there are only limited numbers of studies handling the subject in Turkey. By the present study, PMQR determinants in Salmonella isolated from chicken carcasses were investigated for the first time. This finding has indicated that chicken may be an important vector for the spread of quinolone-resistant Salmonella among animals, as well as from animals to humans through the food chain.

The PMQR determinants in Salmonella isolated from food-producing animals such as chickens are an important public health issue. Preventing the spread of quinolone-resistant Salmonella strains will require the establishment of continuous surveillance program for all resistance determinants at a national level. Furthermore, our results can provide useful information prompting further studies on the prevalence of quinolone-resistant Salmonella spp.

\section{Acknowledgements}

The authors would like to thank Colonel Vet. Med. PhD. Umit Tarakci and Colonel Vet. Med. Specialist Goksel Nursoy (Military Veterinary School Commander, Gemlik, Bursa, Turkey) for their support of this work, Prof. Aysegul Eyigor (Department of Food Hygiene and Technology, Faculty of Veterinary Medicine, Uludag University, Bursa, Turkey) for providing Salmonella isolates and Prof. Recep Cibik (Department of Food Hygiene and Technology, Faculty of Veterinary Medicine, Uludag University, Bursa, Turkey for reviewing the manuscript and English suggestions.

\section{References}

Angulo FJ, Johnson KR, Tauxe RV, Cohen ML 2000: Origins and consequences of antimicrobial-resistant nontyphoidal Salmonella: implications for the use of fluoroquinolones in food animals. Microb Drug Resist 6: $77-83$ 
Avsaroglu MD, Helmuth R, Junker E, Hertwig S, Schroeter A, Akcelik M, Bozoglu F, Guerra B 2007: Plasmidmediated quinolone resistance conferred by qnrS1 in Salmonella enterica serovar Virchow isolated from Turkish food of avian origin. J Antimicrob Chemother 60: 1146-1150

Benenson AS, Chin J 1995: Control of Communicable Diseases Manual. American Public Health Association, Washington, DC, $577 \mathrm{p}$.

Cattoir V, Nordmann P 2009: Plasmid-mediated quinolone resistance in Gram negative bacterial species: an update. Curr Med Chem 16: 1028-1046

Cengiz M, Buyukcangaz E, Arslan E, Mat B, Sahinturk P, Sonal S, Gocmen H, Sen A 2012: Molecular characterisation of quinolone resistance in Escherichia coli from animals in Turkey. Vet Rec 171: 155, 1-4

Cheung TK, Chu YW, Chu MY, Ma CH, Yung RW, Kam KM 2005: Plasmid-mediated resistance to ciprofloxacin and cefotaxime in clinical isolates of Salmonella enterica serotype Enteritidis in Hong Kong. J Antimicrob Chemother 56: 586-589

Clinical and Laboratory Standards Institute (CLSI) 2012a: Methods for Dilution Antimicrobial Susceptibility Tests for Bacteria That Grow Aerobically. $9^{\text {th }}$ edn. Approved standard, Wayne, PA, USA, 88 p.

Clinical and Laboratory Standards Institute (CLSI) 2012b: Performance Standards for Antimicrobial Susceptibility Testing; $22^{\text {nd }}$ informational supplement. Wayne, PA, $188 \mathrm{p}$.

ClustalW2. Available at: www.ebi.ac.uk/Tools/msa/clustalw2/. Last modified September 10, 2012. Accessed September 10, 2012.

De Jong A, Smet A, Ludwig C, Stephan B, De Graef E, Vanrobaeys M, Haesebrouck F 2014: Antimicrobial susceptibility of Salmonella isolates from healthy pigs and chickens (2008-2011). Vet Microbiol 171: 298-306

Ferrari R, Galiana A, Cremades R, Rodriguez JC, Magnani M, Tognim MC, Oliveira TC, Royo G 2011: Plasmidmediated quinolone resistance by genes qnrAl and qnrB19 in Salmonella strains isolated in Brazil. J Infect Dev Ctries 5: 496-498

Grimont PAD, Weill FX 2007: Antigenic Formulas of Salmonella Serovars. $9^{\text {th }}$ edn, WHO Collaborating Centre for Reference and Research on Salmonella, 167 p.

Guner A, Atasever M, Atasever AM 2012: New emerging and re-emerging bacterial foodborne pathogens (in Turkish). Kafkas Univ Vet Fak Derg 18: 889-898

Helmuth R 2000: Antibiotic resistance in Salmonella. In: Wray C, Wray A (Eds): Salmonella in Domestic Animals. CAB International, Wallingford, Oxfordshire, UK, pp: 89-103

Hopkins KL, Wootton L, Day MR, Threlfall EJ 2007: Plasmid-mediated quinolone resistance determinant qnrS1 found in Salmonella enterica strains isolated in the UK. J Antimicrob Chemother 59: 1071-1075

International Standards Organization (ISO) 2002: Microbiology of Food and Animal Feeding Stuffs-Horizontal Method for the Detection of Salmonella spp. ISO 6579:2002 (E). Geneva, Switzerland, 27 p.

Kehrenberg C, Friederichs S, De Jong A, Michael GB, Schwarz S 2006: Identification of the plasmid-borne quinolone resistance gene $q n r S$ in Salmonella enterica serovar Infantis. J Antimicrob Chemother 58: 18-22

Kim KY, Park JH, Kwak HS, Woo GJ 2011: Characterization of the quinolone resistance mechanism in foodborne Salmonella isolates with high nalidixic acid resistance. Int J Food Microb 146: 52-56

Mead PS, Slutsker L, Dietz V, Mccaig LF, Bresee JS, Shapiro C, Griffin PM, Tauxe RV 1999: Food-related illness and death in the United States. Emerg Infect Dis 5: 607-625

Molbak K, Gerner-Smidt P, Wegener HC 2002: Increasing quinolone resistance in Salmonella enterica serotype Enteritidis. Emerg Infect Dis 8: 514-515

Mustak HK, Ica T, Ciftci A, Diker KS 2012: Plasmid-mediated quinolone resistance in Escherichia coli strains isolated from animals in Turkey. Vet J Ankara Univ 59: 255-258

Nazik H, Ilktac M, Ongen B 2009: Prevalence of $q n r A$, qnrB, qnrS and aac(6')-Ib-cr (in qnr-positive isolates) among the ESBL-positive and/or ciprofloxacin-resistant isolates in Turkey. J Chemother 21: 219-221

NCBI/BLAST Home. Available at: http://blast.ncbi.nlm.nih.gov/Blast. Last modified March 20, 2013. Accessed March 20, 2013

NCBI Data Bank. Available at: http://www.ncbi.nlm.nih.gov/. Last modified September 07, 2012. Accessed September 07, 2012

NCBI/Primer-BLAST. Available at: www.ncbi.nlm.nih.gov/tools/primer-blast/. Last modified September 12, 2012. Accessed September 12, 2012

Ozgumus OB, Sandalli C, Sevim A, Celik-Sevim E, Sivri N 2009: Class 1 and class 2 integrons and plasmidmediated antibiotic resistance in coliforms isolated from ten rivers in Northern Turkey. J Microbiol 47: 19-27

Taguchi M, Kawahara R, Seto K, Inoue K, Hayashi A, Yamagata N, Kamakura K, Kashiwagi E 2009: Plasmidmediated quinolone resistance in Salmonella isolated from patients with overseas travelers' diarrhea in Japan. Jpn J Infect Dis 62: 312-314

Tauxe RV 1991: Salmonella: a postmodern pathogen. J Food Protect 54: 563-568

Veldman, K, Cavaco, LM, Mevius D, Battisti A, Franco A, Botteldorn N, Bruneau M, Perrin-Guyomard A, Cerny T, De Frutos Escobar C, Guerra B, Schroeter A, Gutierrez M, Hopkins K, Myllyniemi AL, Sunde M, Wasyl D, Aarestrup FM 2011: International collaborative study on the occurrence of plasmid-mediated quinolone resistance in Salmonella enterica and Escherichia coli isolated from animals, humans, food and environment in European countries. J Antimicrob Chemother 66: 1278-1286

Wang YC, Yeh KS, Chang CC, Hsuan SL, Chen TH 2006: Fluoroquinolone-resistant Salmonella sp. in carcasses. Emerg Infect Dis 12: 351-352 
Yu F, Chen Q, Yu X, Pan J, Li Q, Yang L, Chen C, Zhuo C, Li X, Zhang X, Huang J, Wang L 2011: High prevalence of plasmid-mediated quinolone resistance determinant $a a c\left(6^{\prime}\right)-I b-c r$ amongst Salmonella enterica serotype Typhimurium isolates from hospitalised paediatric patients with diarrhoea in China. Int J Antimicrob Agents 37: 152-155 